\title{
Faktor Risiko yang Berperan pada Mortalitas Sepsis
}

\author{
Desy Dewi Saraswati, Antonius H. Pudjiadi, Mulyadi M. Djer, Bambang Supriyatno, \\ Damayanti R. Syarif, Nia Kurniati \\ Departemen Ilmu Kesehatan Anak Fakultas Kedokteran Universitas Indonesia, Rumah Sakit Cipto \\ Mangunkusumo, Jakarta
}

\begin{abstract}
Latar belakang. Sepsis merupakan penyebab utama kematian bayi dan anak. Status imun pejamu dan malnutrisi merupakan faktor penting yang menentukan luaran pada sepsis. Skor pediatric logistic organ dysfunction (PELOD) adalah sistem skoring disfungsi organ pada sakit kritis, untuk memprediksi mortalitas pasien sepsis.

Tujuan. Mengetahui faktor risiko usia, status gizi, dan skor PELOD terhadap mortalitas sepsis.

Metode. Retrospektif analitik berupa data rekam medis pasien berusia 1 bulan - 18 tahun di PICU RSCM bulan Apri1 - Agustus 2011 dengan diagnosis sepsis menurut kriteria konsensus sepsis internasional.

Hasil. Sembilanpuluh dua dari 209 pasien mengalami sepsis, 22 (23,9\%) di antaranya meninggal. Median usia subjek 15 (rentang 2-192) bulan dengan sebaran terbanyak pada kelompok usia 1 bulan - 1 tahun (62\%). Sebagian besar subjek $(57,61 \%)$ memiliki status gizi kurang. Fokus infeksi tersering adalah infeksi saraf pusat dan gastrointestinal, masing-masing 32 (34,77\%) subjek. Gizi buruk (p<0,001; OR 26,88;IK95\% 4,74-152,61) dan skor PELOD $\geq 20$ ( $\mathrm{p}<0,001$; OR 78,8;IK95\% 14,23-436,36) merupakan faktor risiko yang secara independen berperan terhadap mortalitas sepsis pada anak.

Kesimpulan. Gizi buruk dan skor PELOD $\geq 20$ berperan terhadap mortalitas sepsis pada anak. Usia $<5$ tahun tidak terbukti sebagai faktor risiko mortalitas sepsis pada anak. Sari Pediatri 2014;15(5):281-8.
\end{abstract}

Kata kunci: sepsis, faktor risiko, usia, gizi, skor PELOD

epsis merupakan penyebab utama kematian bayi dan anak di seluruh dunia. Insiden sepsis meningkat dalam 30-40 tahun terakhir di negara maju maupun berkembang. ${ }^{1-3}$ Studi

\footnotetext{
Alamat korespondensi:

Dr. Desy Dewi Saraswati, Sp.A. Bungur Besar XVII No. 17 RT 001/04 Gunung Sahari Selatan Jakarta Pusat. Telp. (021) 8629357. E-mail: desy_dewi@idai.or.id
}

epidemiologi pada tujuh negara bagian (24\% populasi total) di Amerika Serikat, ditunjukkan angka kejadian sepsis berat 0,56 kasus per-1000 populasi pertahun. ${ }^{4}$ Insiden tertinggi ditemukan pada kelompok usia bayi (5,16 kasus per-1000 populasi) dan menurun dengan tajam pada kelompok usia 10-14 tahun (0,2 kasus per-1000 populasi). Studi tersebut juga menemukan lebih dari 4383 kematian per tahun, atau $10,3 \%$ dari total kematian pada 
anak yang disebabkan oleh sepsis berat. ${ }^{4}$ Penelusuran rekam medik internal Divisi Pediatrik Gawat Darurat (PGD) Departemen Ilmu Kesehatan Anak (IKA) Rumah Sakit Cipto Mangunkusumo (RSCM) tahun 2009 menemukan persentase kejadian sepsis 19,3\% dari 502 pasien anak dirawat di Pediatric Intensive Care Unit (PICU) RSCM dengan angka mortalitas $10 \% .^{5}$

Beberapa faktor yang berperan terhadap mortalitas sepsis pada anak meliputi faktor pejamu, mikroorganisme penyebab, serta tata laksana yang diberikan. ${ }^{6-9}$ Status imun pejamu merupakan faktor penting yang menentukan luaran pada sepsis. ${ }^{10}$ Respons pejamu terhadap sepsis bergantung pula terhadap kematangan sistem imunitas. Tahap perkembangan sistem imun menunjukkan bahwa semakin muda usia, semakin sedikit tingkat kematangan sistem imun yang telah dicapai, sehingga semakin rendah pula kemampuan membunuh patogen. ${ }^{10}$ Selain usia muda, imunodefisiensi dapat ditemukan pada kondisi malnutrisi, penyakit kronis, luka bakar, atau penyakit keganasan. ${ }^{4,7-9}$

Hasil penelitian yang ada saat ini masih menunjukkan hasil yang tidak konsisten mengenai peran usia sebagai faktor risiko mortalitas sepsis pada anak. Beberapa studi menunjukkan angka mortalitas yang lebih tinggi pada kelompok usia yang lebih muda. ${ }^{4,11}$ Namun sebaliknya, pada studi lain menemukan hasil sebaliknya, ${ }^{12}$ bahkan ada yang menyatakan bahwa usia tidak berhubungan dengan mortalitas pada sepsis. ${ }^{13}$

Malnutrisi terutama gizi buruk juga merupakan salah satu penyulit yang cukup banyak ditemukan pada pasien anak dengan sepsis. ${ }^{10,14}$ Survei terkini melaporkan angka kejadian malnutrisi yang meliputi gizi kurang dan buruk pada pasien rawat inap di PICU berkisar 10\%-24\%, dengan insiden infeksi dan mortalitas yang tinggi. ${ }^{15,16}$ Komplikasi malnutrisi pada anak dengan sepsis dapat mengenai seluruh sistem, seperti menurunkan respon imun, atrofi, dan mempermudah terjadinya translokasi bakteri saluran cerna akibat peningkatan permeabilitas barier intestinal. Pada akhirnya, anak akan mengalami masa penyembuhan luka yang lebih lama, infeksi lain atau reinfeksi, dan meningkatkan angka kematian. ${ }^{17,18}$ Beberapa studi deskriptif menemukan anak dengan gizi buruk lebih banyak pada kelompok pasien sepsis yang meninggal atau mengalami kerusakan sistem organ lebih banyak. ${ }^{13,19,20}$
Skor pediatric logistic organ dysfunction (PELOD) merupakan suatu sistem skoring yang digunakan untuk mengetahui beratnya disfungsi organ pada seorang anak dengan sakit kritis. Skor yang diberikan pada tiap organ akan meningkat sesuai dengan beratnya disfungsi organ. ${ }^{21-23}$ Validasi penggunaan sistem skoring ini telah dilakukan sejak tahun 2003 melalui studi multisenter dengan sampel pasien yang dirawat di PICU. Skor PELOD menunjukkan keunggulan untuk memprediksi kematian pada pasien yang mengalami sepsis. ${ }^{21,23}$ Metta $\mathrm{dkk}^{19}$ menemukan bahwa anak sepsis dengan skor PELOD 20 memiliki risiko mortalitas sebesar $50 \%$, dan semakin tinggi skor PELOD, probabilitas mortalitas akan semakin meningkat (sensitivitas $54,5 \%$ dan spesifisitas $80,9 \% ; \mathrm{p}<0,05)$. Hal ini menunjukkan bahwa semakin besar efek akumulasi disfungsi organ dan beratnya sepsis, risiko mortalitas akan semakin meningkat. ${ }^{22}$

Sejauh pengetahuan peneliti, hingga saat ini belum banyak data yang memberikan informasi yang memadai tentang faktor risiko mortalitas sepsis pada anak di Indonesia. Selain itu, masih banyak studi di luar negeri yang menunjukkan hasil yang berbeda-beda. Berdasarkan latar belakang tersebut perlu dilakukan penelitian lebih lanjut mengenai peran usia, status gizi dan skor PELOD terhadap mortalitas sepsis pada anak. Hasil penelitian ini juga diharapkan dapat memberikan gambaran secara umum karakteristik pasien sepsis yang dirawat di PICU RSCM.

Tujuan penelitian ini adalah untuk mengetahui peran usia $<5$ tahun, gizi buruk dan skor PELOD $\geq 20$ sebagai faktor risiko mortalitas sepsis pada anak di unit perawatan pediatrik RSCM.

\section{Metode}

Penelitian potong lintang (cross sectional) retrospektif analitik berlangsung di unit perawatan intensif pediatrik PICU RSCM. Data diambil dari rekam medis pasien yang dirawat selama bulan April sampai dengan Agustus 2011. Subjek penelitian adalah anak usia $>1$ bulan $-\leq 8$ tahun dengan diagnosis sepsis, yaitu berdasarkan International Pediatric Sepsis Consensus Conference. ${ }^{24}$ Penelitian ini telah mendapatkan persetujuan dari Komite Etik Penelitian FKUI. 
Data meliputi identitas pasien, nama anak, nomor rekam medis, usia, jenis kelamin, diagnosis (fokus infeksi), dan skor PELOD. Mencatat berat badan, tinggi badan, dan lingkar lengan atas pasien, kemudian menentukan status nutrisi. Pemantauan melalui rekam medis sampai dengan pasien keluar PICU atau meninggal, berupa hasil laboratorium, hasil biakan, pemakaian ventilator, pemakaian inotropik, dan luaran (hidup/meninggal).

Analisis statistik dilakukan dengan program SPSS versi 16.0 menggunakan uji chi-square atau uji Fischer dan analisis multivariat dengan uji regresi logistik. Nilai p dianggap bermakna secara statistik jika $<0,05$.

Tabel 1. Karakteristik subjek sepsis $(\mathrm{n}=92)$

\begin{tabular}{|c|c|c|c|}
\hline Karakteristik & Frekuensi (\%) & Meninggal (\%) & Hidup (\%) \\
\hline \multicolumn{4}{|l|}{ Jenis kelamin } \\
\hline Lelaki & $51(55,4)$ & $14(27,5)$ & $37(72,5)$ \\
\hline Perempuan & $41(44,57)$ & $8(19,5)$ & $33(80,5)$ \\
\hline \multicolumn{4}{|l|}{ Kelompok umur } \\
\hline 1 bulan -1 tahun & $57(62)$ & $14(24,6)$ & $43(75,4)$ \\
\hline $2-5$ tahun & $15(18,5)$ & $1(6,7)$ & $14(93,3)$ \\
\hline $6-12$ tahun & $12(13,0)$ & $4(33,3)$ & $8(66,7)$ \\
\hline $13-<18$ tahun & $8(8,7)$ & $3(37,5)$ & $5(62,5)$ \\
\hline \multicolumn{4}{|l|}{ Status gizi } \\
\hline Cukup & $27(29,34)$ & $4(14,8)$ & $23(85,2)$ \\
\hline kurang & $53(57,61)$ & $10(18,9)$ & $43(81,1)$ \\
\hline Buruk & $12(13,04)$ & $8(66,7)$ & $4(33,3)$ \\
\hline \multicolumn{4}{|l|}{ Fokus infeksi } \\
\hline Sistem saraf pusat & $32(34,77)$ & $13(40,6)$ & $19(59,4)$ \\
\hline Gastrointestinal & $32(34,77)$ & $4(12,5)$ & $28(87,5)$ \\
\hline Respiratorik & $11(11,95)$ & $2(18,2)$ & $9(81,8)$ \\
\hline Urogenital & $9(9,78)$ & $3(33,3)$ & $6(66,7)$ \\
\hline Keganasan & $5(5,43)$ & - & $5(100)$ \\
\hline Lain-lain & $3(3,26)$ & - & $3(100)$ \\
\hline \multicolumn{4}{|l|}{ Pasca-pembedahan } \\
\hline Tidak & $72(78,26)$ & $18(25)$ & $54(75)$ \\
\hline Ya & $20(24,74)$ & $4(20)$ & $16(80)$ \\
\hline \multicolumn{4}{|l|}{ Prokalsitonin ( PCT >2 ng/mL) } \\
\hline$\geq 2-10$ & $55(59,77)$ & $5(9,1)$ & $50(90,9)$ \\
\hline$\geq 10$ & $37(40,22)$ & $17(45,9)$ & $20(54,1)$ \\
\hline \multicolumn{4}{|l|}{ Ventilator } \\
\hline Tanpa ventilator & $59(64,12)$ & $7(11,9)$ & $52(88,1)$ \\
\hline Menggunakan ventilator & $33(35,86)$ & $15(45,5)$ & $18(54,5)$ \\
\hline \multicolumn{4}{|l|}{ Inotropik } \\
\hline Tanpa inotopik & $71(77,17)$ & $5(7,1)$ & $66(92,9)$ \\
\hline Menggunakan inotropik & $21(22,84)$ & $17(80,9)$ & $4(19,1)$ \\
\hline \multicolumn{4}{|l|}{ PELOD Skor } \\
\hline$<20$ & $75(81,52)$ & $8(10,7)$ & $67(89,3)$ \\
\hline$\geq 20$ & $17(18,47)$ & $14(82,4)$ & $3(17,6)$ \\
\hline \multicolumn{4}{|l|}{ Luaran } \\
\hline Hidup & $70(76,1)$ & & \\
\hline Meninggal & $22(23,9)$ & & \\
\hline
\end{tabular}




\section{Hasil}

Selama penelitian berjalan terdapat 209 anak yang masuk perawatan PICU Departemen IKA RSCM. Diagnosis sepsis ditegakkan pada 94 anak, dua anak dieksklusi karena mengalami leukemia, sehingga 92 anak diambil sebagai subjek penelitian.

Sebagian besar subjek berjenis kelamin laki-laki; rasio dibanding perempuan 1,24:1. Median usia subjek penelitian 15 bulan (rentang 2-192) bulan dengan sebaran terbanyak pada kelompok usia 1 bulan-1 tahun (62\%). Sebagian besar subjek $(57,61 \%)$ memiliki status gizi kurang dan 13,04\% gizi buruk. Duapuluh satu $(22,8 \%)$ subjek membutuhkan bantuan zat vasoaktif (inotropik) karena mengalami syok septik. Fokus infeksi yang tersering dijumpai adalah infeksi susunan saraf pusat dan infeksi gastrointestinal, masing-masing terdapat $32(34,77 \%)$ subjek. Karakteristik subjek penelitian tertera pada Tabel. 1 .

\section{Distribusi hasil biakan}

Limapuluh tujuh koma enam persen subjek (53/92) mempunyai hasil biakan positif. Tigapuluh sembilan persen (37/94) hasil pemeriksaan biakan darah positif terhadap Pseudomonas (7,4\%). Limapuluh tujuh koma delapan persen (26/45) spesimen urin, dan 38,1\% $(8 / 21)$ spesimen cairan tubuh lain (sputum, cairan serebrospinal, pipa endotrakeal, dan cairan asites) juga menunjukkan hasil positif. Distribusi jenis kuman dari hasil biakan tertera pada Tabel. 2 .

\section{Faktor risiko yang berperan terhadap mortalitas} pada sepsis

\section{Usia}

Variabel usia dibagi menjadi kelompok kurang dari 5 tahun dan lebih sama dengan 5 tahun. Pembatasan usia 5 tahun diambil dengan pertimbangan bahwa pada usia tersebut sebagian besar sistem imun pejamu diharapkan sudah matur. Kedua variabel ini dibandingkan dengan menggunakan uji chi square. Hasil analisis menunjukkan bahwa subjek pada kelompok usia $<5$ tahun memiliki risiko meninggal 0,6 kali dibandingkan dengan kelompok $\geq 5$ tahun, tetapi secara statistik hasil tersebut tidak bermakna.

\section{Status gizi}

Hasil analisis menunjukkan bahwa kelompok subjek dengan status gizi buruk memiliki risiko meninggal 9,43 kali dibandingkan dengan status gizi baik atau kurang, dan hasil ini bermakna secara statistik.

\section{Skor PELOD}

Hasil analisis menunjukkan bahwa kelompok subjek dengan skor PELOD $\geq 20$ memiliki risiko meninggal 39,08 kali dibandingkan dengan skor PELOD $<20$, dan hasil ini bermakna secara statistik. Tabel 3 Memperlihatkan hasil uji analitik kelompok usia, status gizi, dan skor PELOD terhadap mortalitas sepsis.

Analisis multivariat faktor risiko mortalitas pada anak sepsis

Ketiga variabel bebas yang dianggap sebagai faktor

Tabel 2. Distribusi kuman pada biakan

\begin{tabular}{lcccc}
\hline Jenis kuman & $\begin{array}{c}\text { Biakan darah }(\%) \\
(\mathrm{n}=94)^{*}\end{array}$ & $\begin{array}{c}\text { Biakan urin } \\
(\mathrm{n}=45)\end{array}$ & $\begin{array}{c}\text { Biakan feses } \\
(\mathrm{n}=6)\end{array}$ & $\begin{array}{c}\text { Jaringan lain } \\
(\mathrm{n}=21)\end{array}$ \\
\hline Klebsiella pneumonia & $6(6,4)$ & 2 & - & - \\
Pseudomonas & $7(7,4)$ & 2 & - & 4 \\
Escherichia coli & $5(5,3)$ & 7 & 5 & - \\
Staphylococcus epidermidis & $5(5,3)$ & 2 & - & 1 \\
Acinetobacter sp. & $4(4,3)$ & 3 & - & 1 \\
Candida sp. & $3(3,2)$ & 3 & - & - \\
Burkholderia cepacia & $2(2,1)$ & - & - & - \\
Serratia marcesens & $2(2,1)$ & - & - & - \\
Streptococcus pneumoniae & $2(2,1)$ & - & - & - \\
Enterobacter sp. & $1(1,1)$ & - & 1 & 1 \\
Streptococcus alpha-hemolyticus & - & - & - & - \\
Streptococcus viridans & $57(60,6)$ & 19 & - & 1 \\
Steril & & - & - & 13 \\
\hline
\end{tabular}

*dari 92 subjek terdapat 94 hasil biakan darah (2 subjek dilakukan pemeriksaan biakan darah ulang karena keadaan klinis memburuk selama perawatan). 
risiko yang berperan terhadap mortalitas pada pasien sepsis memiliki nilai $\mathrm{p}<0,25$ dalam analisis bivariat, sehingga dapat diikutkan dalam analisis multivariat (Tabel 4). Analisis regresi logistik digunakan sebagai analisis multivariat pada penelitian ini karena variabel dependen (luaran) merupakan variabel kategorikal.

Tabel. 3 Analisis bivariat beberapa faktor risiko yang berperan terhadap mortalitas subjek sepsis

\begin{tabular}{lcc}
\hline Faktor risiko & OR (IK 95\%) & Nilai p \\
\hline Kelompok usia $<5$ tahun* & $0,6(0,28-1,26)$ & 0,24 \\
Status gizi buruk** & $9,43(2,49-35,71)$ & 0,001 \\
Skor PELOD $\geq 20^{* *}$ & $39,08(9,2-166,04)$ & $<0,001$ \\
\hline
\end{tabular}

* uji chi square

** uji Fisher pada penelitian ini proporsi mortalitas pada kelompok usia 1 bulan - 1 tahun lebih banyak dibandingkan kelompok usia lain.

Studi epidemiologi oleh Watson $\mathrm{dkk}^{4}$ menemukan angka kematian akibat sepsis di Amerika Serikat paling tinggi pada usia 1-12 bulan dan lebih tinggi secara bermakna pada anak dengan penyakit penyerta. Maat $\mathrm{dkk}^{11}$ menemukan risiko mortalitas yang lebih tinggi pada anak di bawah usia 3 tahun. Sementara penelitian oleh Markovitz dkk ${ }^{12}$ memperlihatkan angka kematian yang lebih tinggi pada usia yang lebih tua (13-17 tahun vs neonatus).

Tahap perkembangan sistem imun menunjukkan bahwa semakin muda usia, semakin sedikit tingkat kematangan sistem imun yang telah dicapai sehingga semakin rendah pula kemampuan eradikasi patogen.

Tabel 4. Analisis multivariat faktor risiko yang berperan terhadap mortalitas sepsis

\begin{tabular}{lcccccc}
\hline Variabel & Koefisien & S.E & Wald & df & Nilai p & OR (IK95\%) \\
\hline Langkah 1b & & & & & & \\
Gizi buruk & 3,29 & 0,89 & 13,80 & 1 & $<0,001$ & $26,88(4,74-152,61)$ \\
PELOD $\geq 20$ & 4,37 & 0,87 & 25,01 & 1 & $<0,001$ & $78,80(14,23-436,36)$ \\
Konstanta & $-10,71$ & 1,99 & 29,09 & 1 & $<0,001$ & \\
\hline
\end{tabular}

Uji regresi logistik; OR=odds ratio/risiko odds, IK95\%= interval kepercayaan 95\%

Setelah dilakukan analisis multivariat dengan uji regresi logistik didapatkan faktor yang bermakna secara statistik memengaruhi luaran berupa kematian pada anak sepsis adalah skor PELOD $\geq 20$, dengan nilai OR 78,8 (IK95\%14,23-436,36; $\mathrm{p}<0,001$ ) dan status gizi buruk, dengan nilai OR 26,88 (IK95\% 4,74-152,61; $\mathrm{p}<0,001)$.

\section{Pembahasan}

Penelitian kami membagi variabel usia menjadi kelompok kurang dari 5 tahun dan lebih sama dengan 5 tahun. Pembatasan usia 5 tahun diambil dengan pertimbangan bahwa pada usia tersebut sebagian besar sistem imun pejamu diharapkan sudah matur dan berdasarkan pembagian kelompok usia menurut konsensus sepsis internasional. ${ }^{10,24}$ Kedua kelompok usia tidak mempunyai perbedaan sebagai faktor risiko yang berperan terhadap mortalitas sepsis pada anak. Hal tersebut sesuai dengan penelitian Villegas $\mathrm{dkk}^{13}$ yang tidak melaporkan usia sebagai faktor risiko yang berperan terhadap mortalitas sepsis pada anak. Namun,
Hal tersebut dapat meningkatkan risiko kematian pada anak dengan usia muda yang mengalami sepsis. ${ }^{10}$ Namun, teori yang menyatakan bahwa respon pejamu terhadap sepsis bergantung pula terhadap kematangan sistem imunitas belum dapat dibuktikan dari penelitian ini. Pada penelitian ini proporsi mortalitas pada kelompok usia 1 bulan -1 tahun lebih banyak dibandingkan kelompok usia lain, tetapi tidak terbukti merupakan faktor risiko mortalitas pada sepsis.

Kami mendapatkan hubungan antara status gizi dengan mortalitas sepsis pada anak. Risiko mortalitas pada kelompok status gizi buruk meningkat 9,43 kali dibandingkan dengan status gizi baik dan kurang, dan risiko ini meningkat 26,88 kali pada analisis multivariat yang melibatkan variabel usia dan skor PELOD $\geq 20$.

Keadaan malnutrisi terutama gizi buruk dapat meningkatkan kerentanan pejamu terhadap penyakit, terutama pada anak, serta menimbulkan imunodefisiensi sekunder. Ditambah lagi, infeksi sendiri dapat menimbulkan malnutrisi terutama gizi buruk pada pejamu akibat meningkatnya metabolisme. ${ }^{25}$ Penelitian 
ini sesuai dengan studi oleh Villegas $\mathrm{dkk}^{13}$ menemukan anak dengan malnutrisi (gizi kurang dan buruk) lebih banyak $(49,1 \%)$ pada kelompok pasien sepsis yang meninggal dibandingkan dengan yang bertahan hidup $(35,5 \%)$ demikian pula studi oleh Metta $\mathrm{dkk}^{19}$ (6 malnutrisi berat dari 11 subjek meninggal vs 3 malnutrisi berat dari 21 subjek hidup).

Penelitian serupa pada dewasa oleh Correia $\mathrm{dkk}^{18}$ juga menunjukkan malnutrisi (terutama gizi buruk) sebagai faktor risiko terhadap terjadinya komplikasi penyakit dan peningkatan mortalitas. Pada penelitan yang sama didapatkan risiko malnutrisi (terutama gizi buruk) terhadap mortalitas meningkat 1,87 kali pada analisis multivariat.

Kami mendapatkan hubungan antara skor PELOD dengan mortalitas sepsis pada anak. Risiko mortalitas sebesar 39,08 kali pada kelompok skor PELOD $\geq 20$ dibandingkan skor PELOD $<20$, dan risiko ini meningkat 78,826 kali pada analisis multivariat yang melibatkan variabel usia dan gizi buruk.

Skor PELOD ditemukan oleh Leteurtre dkk..$^{21,23,26}$ Skor ini meliputi sistem kardiovaskular, sistem pernapasan, sistem saraf, sistem hematologi, sistem hati, dan sistem ginjal. Tiap kegagalan organ akan mendapatkan nilai 0 hingga 20 dan total maksimal skor PELOD adalah 71. ${ }^{26}$ Skor PELOD berguna untuk memprediksi kematian pada pasien dengan sakit berat, dan dapat digunakan berulang kali karena kegagalan dari tiap organ dapat dinilai dari waktu ke waktu sejak masuk PICU hingga 2 jam sebelum meninggal atau keluar dari PICU. ${ }^{21,27}$

Watson $\mathrm{dkk}^{4}$ menyatakan bahwa risiko kematian akan meningkat apabila terdapat kegagalan fungsi organ yaitu dari $7 \%$ pada kegagalan satu organ menjadi $53,1 \%$ pada kegagalan $\geq 4$ organ. Chakravarty $\mathrm{dkk}^{28}$ juga menyebutkan bahwa apabila terdapat kegagalan multi organ, maka angka kematian dapat mencapai $80 \%$. Skor PELOD ini menilai perubahan disfungsi organ secara klinis sehingga dapat menggambarkan dan menilai kuantitas derajat beratnya penyakit secara akurat dan objektif serta secara tidak langsung memprediksi mortalitas. ${ }^{23,29,30}$

Penelitian kami serupa dengan penelitian yang didapatkan oleh Metta dan Honna yaitu studi mengenai penggunaan skor PELOD untuk menilai prognosis pasien PICU. ${ }^{19,31}$ Metta $\mathrm{dkk}^{19}$ melaporkan peningkatan skor PELOD berkorelasi positif kuat dengan peningkatan probabilitas kematian. Pada penelitian tersebut spesifisitas tertinggi terdapat pada probabilitas kematian 50\% dengan skor PELOD 20 (sensitivitas 54,5\%, spesifisitas 80,9\%, nilai duga positif 60 , nilai duga negatif 77,3 , dan rasio kemungkinan 2,4). Honna $\mathrm{dkk}^{31}$ melaporkan skor PELOD 20,5 memiliki sensitivitas $81,1 \%$ dan spesifitas $77,3 \%$ dalam menentukan probabilitas kematian.

Dengan hasil yang diperoleh dapat disimpulkan bahwa status gizi buruk dan skor PELOD $\geq 20$ merupakan faktor risiko independen yang berperan terhadap mortalitas anak dengan sepsis di PICU RSCM. Risiko mortalitas akan semakin meningkat pada pasien sepsis yang memiliki status gizi buruk dan skor PELOD $\geq 20$.

Berdasarkan hasil penelitian kami dapat dipikirkan bahwa intervensi yang dapat dilakukan untuk untuk mengurangi mortalitas pasien sepsis di PICU RSCM adalah dengan memperbaiki tata laksana penyakit dan nutrisi pasien selama perawatan.

\section{Kesimpulan}

Gizi buruk terbukti sebagai faktor risiko mortalitas sepsis pada anak dan skor PELOD $\geq 20$ terbukti sebagai faktor risiko mortalitas sepsis pada anak. Sedangkan usia $<5$ tahun tidak terbukti sebagai faktor risiko mortalitas sepsis pada anak. Perlu dilakukan penelitian lebih lanjut dengan metode kohort terhadap faktor risiko yang meliputi pejamu, mikroorganisme dan tata laksana yang berperan terhadap mortalitas sepsis pada anak.

\section{Daftar pustaka}

1. Proulx F, Fayon M, Farrell CA, Lacroix J, Gauthier M. Epidemiologi of sepsis and multiple organ dysfunction syndrome in children. Chest 1996;109:1033-7.

2. Khan MR, Maheswari PK, Masood K, Qamar FN, Haque A. Epidemiology and outcome of sepsis in a tertiary care PICU of Pakistan. Indian J Pediatr 2012;12:34-40.

3. Shime N, Kawasaki T, Saito O, Akamine Y, Toda Y, Takeuchi M dkk. Incidence and risk factors for mortality in paediatric severe sepsis: results from the national paediatric intensive care registry in Japan. Intensive Care Med 2012;12:25-32.

4. Watson S, Carcillo JA, Linde-Zwirble WT, Clermont G, 
Lidicker J, Angus DC. The epidemiology of severe sepsis in children in the United States. Am J Respir Crit Care Med 2003;167:695-701.

5. Rekam Medis Departemen Ilmu Kesehatan Anak RSCM: data pasien di Unit Perawatan Intensif Pediatrik tahun 2009.

6. Balentine JR. Sepsis. [Diakses tanggal 5 Februari 2012]. Diunduh dari:http://www.emedicinehealth.com/sepsis_blood_ infection/page8_em.htm.

7. Erdem G. Sepsis. [Diakses tanggal 5 Februari 2012]. Diunduh dari: http://www.hawaii.edu/medicine/pediatrics/ pedtext/s06c16.html.

8. Martinot A, Leclerc F, Cremer R, Leteurtre S, Fourier $\mathrm{C}$, Hue V. Sepsis in neonates and children: definitions, epidemiology, and outcome. Pediatr Emerg Care 1997;13:277-81.

9. Gogos CA, Lekkou A, Papageorgiou O, Siagris D, Skoutelis A, Bassaris HP. Clinical prognostic markers in patients with severe sepsis: a prospective analysis of 139 consecutive cases. J Infect 2003;47:300-6.

10. Wynn J, Cornell TT, Wong HR, Shanley TP, Wheeler DS. The host response to sepsis and developmental impact. Pediatrics 2010;125:1031-41.

11. Maat M, Buysse CM, Emonts M, Spanjaard L, Joosten KF, de Groot R, dkk. Improved survival of children with sepsis and purpura: effects of age, gender, and era. Crit Care 2007;11:1-10.

12. Markovitz BP, Goodman DM, Watson RS, Bertoch D, Zimmerman J. A retrospective cohort study of prognostic factors associated with outcome in pediatric severe sepsis: what is the role of steroids? Pediatr Crit Care Med 2005;6:270-4.

13. Villegas D, Echandia CA. Factors associated with mortality through sepsis syndrome in children 31 days to 14 years of age. Hospital Universitario Del Valle, Cali. [Diakses tanggal 4 Februari 2012]. Diunduh dari: http:// colombiamedica.univalle.edu.co/index.php/comedicalarticlel viewArticle/727/1188.

14. Menezes FS, Leite HP, Nogueira PCK. Malnutrition as an independent predictor of clinical outcome in critically ill children. Nutrition 2012;28:267-70.

15. Briassoulis G, Zavras N, Hatzis T. Malnutrition, nutritional indices and early enteral feeding in critically ill children. Nutrition 2001;17:548-57.

16. Hulst J, Joosten K, Zimmermann L, Hop W, Van Buuren S, dkk. Malnutrition in critically ill children: from admission to 6 month after discharge. Clin Nutr 2004;23:223-32.

17. Corish CA, Kennedy NP. Protein-energy undernutrition in hospital inpatients. Br J Nutr 2000;83:575-91.

18. Correia MITD, Waitzberg DL. The impact of malnutrition on morbidity, mortality, length of hospital stay and cost evaluated through a multivariate model analysis. Clin Nutr 2003;22:235-9.

19. Metta D, Soebardja D, Soemasetia DH. The use of Pediatric Logistic Organ Dysfunction (PELOD) scoring system to determine the prognosis of patients in pediatric intensive care units. Pediatr Indones 2006;46:1-6.

20. Hendra, Runtunuwu AL, Manoppo JIC. Pediatric logistic organ dysfunction (PELOD) score as prognosis of multiple organ failure in sepsis. Paediatr Indones 2010;50:226-32.

21. Lacroix J, Cotting J. Severity of illness and organ dysfunction scoring in children. Pediatr Crit Care Med 2005; 6:126-34

22. Leclerc F, Leteurtre S, Duhamel A, Grandbastiaen B, Proulx F, Gauvin F, dkk. Cumulative influence of organ dysfunction and septic state on mortality of critically ill children. Am J Respir Crit Care Med 2005; 171:34853.

23. Leteurtre S, Martinot A, Duhamel A, Proulx F, Grandbastien B, Cotting J, dkk. Validation of the pediatric logistic organ dysfunction score: prospective, observational, multicenter study. Lancet 2003;362:1927.

24. Goldstein B, Giroir Brett, Randolph A, the Members of the International Consensus Conference on Pediatric Sepsis. International pediatric sepsis consensus conference: definitions for sepsis and organ dysfunction in pediatrics. Pediatr Crit Care Med 2005;6:2-8.

25. Schaible UE, Kaufmann SHE. Malnutrition and infection: Complex mechanisms and global impacts. J Pmed 2007;4:0806-12.

26. Leteurtre S, Martinot A, Duhamel A, Gauvin F, Grandbastien B, Nam TV, dkk. Development of pediatric multiple organ dysfunctions score: use of two strategies. Med Decis Making 1999; 19:399-410.

27. Enrione MA, Powell KR. Sepsis, septic shock, and systemic inflammatory response syndrome. Dalam: Kleigman RM, Behrman RE, Jenson HB, Stanton BF, penyunting. Nelson textbook of pediatrics. Edisi ke-18. Philadelphia: Elsevier Inc;2007. h.1094-9.

28. Chakravarty A, Chatterjee SK. Sepsis and neurology. JAPI 2003;51:385-90.

29. Han YY, ShanleyTP. Multiple organ dysfunction syndrome. Dalam: Nichols DG, penyunting. Roger's textbook of pediatric intensive care. Edisi ke-4. Philadelphia: Lippincott Williams \& Wilkins;2008.h.283-7 
30. Leteurtre S, Martinot A, Duhamel A, Gauvin F, Grandbastien B, Nam TV, dkk. Development of pediatric multiple organ dysfunctions score: use of two strategies. Med Decis Making 1999; 19:399-410.
31. Honna L, Triratna S, Triwani, Theodorus. Use of pediatric logistic organ dysfunction (PELOD) in determining prognostic among pediatric intensive care unit patients. Paediatr Indones 2010;50:347-50. 